\title{
How to Mitigate Corruption in Emerging Markets: The Case of Russia
}

\author{
Stanislav Shekshnia \\ Professor, INSEAD \\ Alena V. Ledeneva \\ Professor, UCL \\ Elena Denisova-Schmidt
}

Network Fellow, Edmond J. Safra Center for Ethics 


\section{Edmond J. Safra Working Papers, No. 36}

About this Working Paper Series: In 2010, Lawrence Lessig launched the Edmond J. Safra Research Lab, a major initiative designed to address fundamental problems of ethics in a way that is of practical benefit to institutions of government and society around the world. As its first undertaking, The Edmond J. Safra Research Lab is tackling the problem of Institutional Corruption. On March 15, 2013, this Working Paper series was created to foster critical resistance and reflection on the subject of Institutional Corruption. http:/ / www.ethics.harvard.edu/lab

How to Mitigate Corruption in Emerging Markets: the Case of Russia by Stanislav Shekshnia, Alena V. Ledeneva, Elena Denisova-Schmidt

Edmond J. Safra Research Lab Working Papers, No. 36

Harvard University 124 Mount Auburn Street, Suite 520N, Cambridge, MA 02138

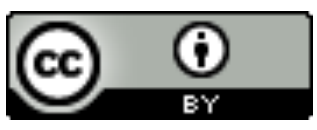

This work is licensed under a Creative Commons Attribution 3.0 Unported License. http://creativecommons.org/licenses/by/3.0/deed.en_US 


\section{Abstract}

Russian CEOs are arguably the most experienced managers in the world when it comes to working in corrupt environments. For our analysis, we gathered data from the CEOs and owners of 111 local and international companies operating in Russia. We asked them to assess their experiences with informal practices, including the extent to which their businesses are dependent on informal deals and the strategies they deploy to mitigate business corruption. The list of specific practices and strategies assembled in the pilot interviews and media content analysis has been cross-checked with the existing typologies of corruption in post-communist societies and verified through in-depth interviews.

This study presents the outcomes of our analysis, one of which is that companies tend to blame officials for corrupt activities while hiding their own internal corruption from public view. Both are dependent on the industry in which they operate, however. The paper also includes the approach we developed to understand the less reprehensible but more widespread forms of corruption such as collusion, conflict of interest, cronyism and nepotism, fraud, gifts and hospitality, lobbying, abuse of power or office, and influence peddling.

Note: The original version of this article appeared as Stanislav Shekshnia, Alena Ledeneva and Elena Denisova-Schmidt, "Reflective Leadership vs. Endemic Corruption: Managing Corruption in Emerging Markets," INSEAD Working Paper No. 2013/121/EFE (2013), http://ssrn.com/abstract=2373889, but has been significantly reworked with reference to inner-company corruption.

Keywords: Institutional Corruption, Russia, Informal Practices, Leadership 


\section{Introduction}

Corruption remains one of the main challenges in doing business in many countries. ${ }^{1}$ Analyzing this phenomenon from many different perspectiveseconomic, managerial, sociological, psychological, anthropological and institutional-scholars and practitioners have underlined its negative impact. ${ }^{2}$ The increase in expertise on this topic, together with the longstanding efforts by such international agencies as the IMF and the World Bank as well as national governments, has not led to any effective control of business corruption, however, especially in fast-growing economies like China, India, Brazil, Indonesia and Russia. ${ }^{3}$ Examining current initiatives companies have undertaken to manage the risk of corruption, PricewaterhouseCoopers found that only $22 \%$ of firms are confident of the effectiveness of the anti-corruption programs they already have. ${ }^{4}$

Our paper introduces special tools for monitoring corruption when doing business in Russia-tools that might also be applicable for other emerging markets. Russia is an interesting case. Not only is it the second-largest emerging economy in the

\footnotetext{
${ }^{1}$ See Raymond Fisman and Jakob Svensson, "Are Corruption and Taxation Really Harmful to Growth? Firm Level Evidence," Journal of Development Economics 83.1 (2007): 63.75; Roberto Martin N. Galang, "Victim or Victimizer: Firm Responses to Government Corruption," Journal of Management Studies 49.2 (2012): 429.462; Stephen Knack and Philip Keefer, "Institutions and Economic Performance: Cross-Country Tests Using Alternative Institutional Indicators," Economics and Politics 7.3 (1995): 207-228; Paolo Mauro, "Corruption and Growth," Quarterly Journal of Economics 110.3 (1995): 681-712; Andrei Shleifer and Robert W. Vishny, "Corruption," Quarterly Journal of Economics 108.3 (1993): 599-617; Steven Globerman and Daniel Shapiro, "Governance Infrastructure and U.S. Foreign Direct Investment," Journal of International Business Studies 34.1 (2003): 19-39; and Kathleen A. Getz and Roger J. Volkema, "Culture, Perceived Corruption and Economics: A Model of Predictors and Outcomes," Business Society 40.1 (2001): 7-30.

2 Susan Rose-Ackerman, Corruption: A Study in Political Economy (Academic Press, 1978); Douglass C. North Institutions, Institutional Change and Economic Performance (Cambridge University Press, 1990); Oliver E. Williamson, "Comparative Economic Organization: The Analysis of Discrete Structural Alternatives," Administrative Science Quarterly 36.2 (1991): 269-296; Bryan W. Husted, "Wealth, Culture, and Corruption," Journal of International Business Studies 30.2 (1999): 339-359; Rafael La Porta, Florencio Lopez-De-Silanes and Andrei Shleifer, "Corporate Ownership Around the World," Journal of Finance 54.2 (1999): 471-517; Jong-Sung You and Sanjeev Khagram, "A Comparative Study of Inequality and Corruption," American Sociological Review 70.1 (2005): 136-157; Lawrence Lessig, "Institutional Corruptions," Edmond J. Safra Research Lab Working Papers, No. 1, March 15, 2013, http://papers.ssrn.com/sol3/papers.cfm?abstract_id=2233582; and Dennis Thompson, "Two Concepts of Corruption," Edmond J. Safra Research Lab Working Papers, No. 16, August 1, 2013, http://papers.ssrn.com/sol3/papers.cfm?abstract_id=2304419.

${ }^{3}$ See indexes for all countries at http://www.heritage.org/index/country/russia.

${ }^{4}$ The PricewaterhouseCoopers Report, "Confronting Corruption: The Business Case for an Effective AntiCorruption Programme," is available online at http://www.pwc.com/gx/en/forensic-accounting-disputeconsulting-services/business-case-anti-corruption-programme.jhtml. The report is based on a survey of 390 senior executives, supplemented with in-depth interviews with 36 senior executives and experts in anticorruption efforts from 14 countries. It examines the current and possible future actions companies perform to manage the risk of corruption.
}

EDMOND J. SAFRA RESEARCH LAB, HARVARD UNIVERSITY • HOW TO MITIGATE CORRUPTION IN EMERGING 
world after China, it is also labeled as one of the most corrupt countries. ${ }^{5}$ In recent years, the Russian government has undertaken significant anti-corruption efforts in line with Organisation for Economic Co-operation and Development (OECD), World Trade Organization (WTO) and World Bank policy recommendations, but the results of such efforts at company level are far from encouraging.

\section{Business Corruption in Russia}

Although the theme of business corruption in Russia has been widely researched in a comparative context (BEEPS), ${ }^{6}$ research has mainly focused on general perceptions of corruption and specific forms of corruption such as bribe-taking, which can be measured. In 2010, Russia ranked at the bottom of 22 countries assessed in Transparency International's Bribe Payers Index. However, little is known about other forms of corporate corruption, such as collusion, conflicts of interest, cronyism and nepotism, fraud, gifts and hospitality, lobbying, and influence-peddling which are arguably more widespread.

Such an incomplete picture offers fertile ground for the emergence of popular perceptions of the origins and nature of business corruption in Russia, the most popular being that corrupt government officials at all levels extort rents from innocent businesses, which suffer from bureaucratic red-tape and are forced to engage in shadowy practices.

In [my] region, according to an agreement with the unions, the monthly recommended minimum wage is about USD 180. Both the regional pension fund and the regional administration put pressure on businesses to pay at least that. So that's what I do, I pay my employees USD 180 minimal wage. Officially. The rest they get in the envelopes. I do it because if I showed the real wage, about USD 750,13\% must be paid in personal tax by employee, another $24 \%$ goes for social tax and other payments—roughly, one third has

\footnotetext{
${ }^{5}$ Transparency International's Bribe Payers Index measures the perception of corporate corruption, rather than the perception of public sector corruption reflected in the aggregate Corruption Perception Index, where in 2013 Russia placed at 127 out of 177 countries.

${ }^{6}$ The Business Environment and Enterprise Performance Survey (BEEPS) is a joint initiative of the European Bank for Reconstruction and Development (EBRD) and the World Bank. The survey focusses on firms in Eastern Europe and Central Asia, assessing business development and environment. See more at http://www.enterprisesurveys.org/.
} 
to go to the state. Moreover, I have to pay office rent, depreciation, accessories' cost, electricity bills, Internet bills, etc., so in the end I work with losses. The laws are made so that you have to pay one third just for doing business ... they [the state] provoke the entrepreneur in some way to make shadow business, not showing all of the income and expenses, making a secret of commerce.

To shed some light on business corruption in Russia, its scope and impact on business, and to understand how business leaders perceive corruption and seek to mitigate its impact, we conducted a survey of business leaders and complemented it with in-depth interviews and executive workshops to frame the outcomes of the survey. We devised an approach based on "slicing" corruption into constituent informal practices, and collected data on 111 companies, which allowed us to gain insights into the workings of firms in endemically corrupt environments. We consider the results of this survey worth sharing.

\section{Empirical Data}

The proposed approach allowed us to monitor the occurrence of informal practices in daily business operations, to assess the extent to which informal practices prevail in corporate settings, and to identify blind spots which are not addressed by existing anti-corruption strategies at company level. Informal practices are best defined as regular sets of strategies used by actors for getting things done while navigating multiple sets of rules and constraints, both formal and informal, legal and ethical, written and unwritten. ${ }^{7}$ Informal practices adjust to changing legal frameworks and social norms, and evolve to reflect changes in the rules of the game. ${ }^{8}$ The data can improve the robustness of the corresponding anti-corruption strategies. We devised a questionnaire for CEOs, owners, and board members that

\footnotetext{
${ }^{7}$ Alena V. Ledeneva, How Russia Really Works: The Informal Practices that Shaped Post-Soviet Politics and Business (Cornell University Press, 2006).

${ }^{8}$ Alena Ledeneva and Stanislav Shekshnia, "Doing Business in Russia: Informal Practices and Anti-Corruption Strategies," Russie.Nei.Visions 58 (2011), http://www.ifri.org/?page=contributiondetail\&id=6474\&id_provenance=97\&lang=uk, accessed November 12, 2013, and Elena Denisova-Schmidt, "Corruption and Informal Practices in Russia," Euxeinos: Online Journal of the Center for Governance and Culture in Europe 7 (2012): 3.19, http://www.gce.unisg.ch/de/Euxeinos, accessed November 12, 2013.
} 
included a list of informal practices defined on the basis of the multi-stage process outlined below.

At the exploratory stage, we examined existing typologies of corruption and conducted a content analysis of the Russian business media in order to identify corrupt practices that correspond to these types. We conducted interviews with Russian CEOs and directors who were asked to comment on their familiarity with each practice, as well as its frequency. While such practices may not be perceived as corrupt by their protagonists, they nourish the corrupt environment indirectly. For example, one of the executives surveyed, who runs a transportation company, explained that the firm's service centers routinely offer repair and car-wash free of charge for the traffic police because "they have such a small budget for repairing their police cars."

The list of specific practices, assembled in pilot interviews and content-analysis of the media, was cross-checked with and adapted from existing typologies of corruption in post-communist societies ${ }^{9}$ and informal practices. ${ }^{10,11}$

In our test survey, we reserved a space for respondents to add to our list of informal practices. Only two practices were added. In addition to the obvious

${ }^{9}$ Vito Tanzi, "Corruption Around the World: Causes, Consequences, Scope, and Cures," IMF Staff Papers 45.4 (1998): 559-594; Rasma Karklins, The System Made Me Do It: Corruption in Post-Communist Societies (M. E. Sharpe, 2005); and Stephen Knack, "Measuring Corruption in Eastern Europe and Central Asia: A Critique of Cross-Country Indicators," World Bank Policy Research Working Paper No. 3936 (2006).

10 Ledeneva, How Russia Really Works; Alena Ledeneva, "From Russia with Blat: Can Informal Networks Help Modernize Russia?" Social Research 76.1 (2009): 257-288; and Alena V. Ledeneva, Can Russia Modernise? Sistema, Power Networks and Informal Governance (Cambridge University Press, 2013).

11 Types are observed and articulated with reference to degree (petty, administrative, state capture); frequency (routine or extraordinary, exercised by many or by few); motivation (coercive or collusive); level (centralized or decentralized); or scale (predictable or arbitrary). All of these are variations on the theme of deviance and are described in terms that are unlikely to be used by participants in corrupt practices. See Michael Johnston, "The Political Consequences of Corruption: A Reassessment," Comparative Politics 18.4 (1986): 459-477; Michael Johnston, Syndromes of Corruption: Wealth, Power and Democracy (Cambridge University Press, 2005); Tanzi, "Corruption Around the World"; and Rasma Karklins, The System Made Me Do It.

In a 2006 World Bank paper, which adopts the Transparency International definition of corruption as "the misuse of entrusted power for private gain," economist Stephen Knack (2006) organizes these variations into six dimensions of corruption: by level of political system (central government, provincial, municipal), roughly corresponding to the terms "petty" and "grand" corruption; by purpose of the improper actions, to influence the content of laws and rules ("state capture") or to influence their implementation ("administrative corruption"); by the actors involved in the corrupt transaction—various combinations of firms, households and public officials; by characteristics of a particular set of actors, for example, bribes required for large versus small firms, or for rich versus poor households; by administrative agency or service-tax and customs, business licenses, inspections, utility connections, courts or public education and health facilities; and by the incidence or magnitude of bribes or by the uncertainty they create for businesses and households. Knack, "Measuring Corruption in Eastern Europe and Central Asia." 
reasons why open choice prompts in survey questions remain unanswered, ${ }^{12}$ the low number of additions could be interpreted as support for the sufficiency of the existing list, or for the unarticulated nature of informal practices for those who use them routinely.

In the introduction to the survey, we used the term "informal practices" to refer to sets of strategies commonly used by actors to get things done. We asked the participants to report anonymously to what extent their firm engaged in each practice and strategy, choosing from three possible answers: systematically, sometimes, never. Anonymity was emphasized and preserved, even where it created limitations to our analysis.

As illustrated in Figures $1 \mathrm{a}, 1 \mathrm{~b}$ and $1 \mathrm{c}$, a broad range of companies (by size, industry, and ownership structure) was represented in the sample.

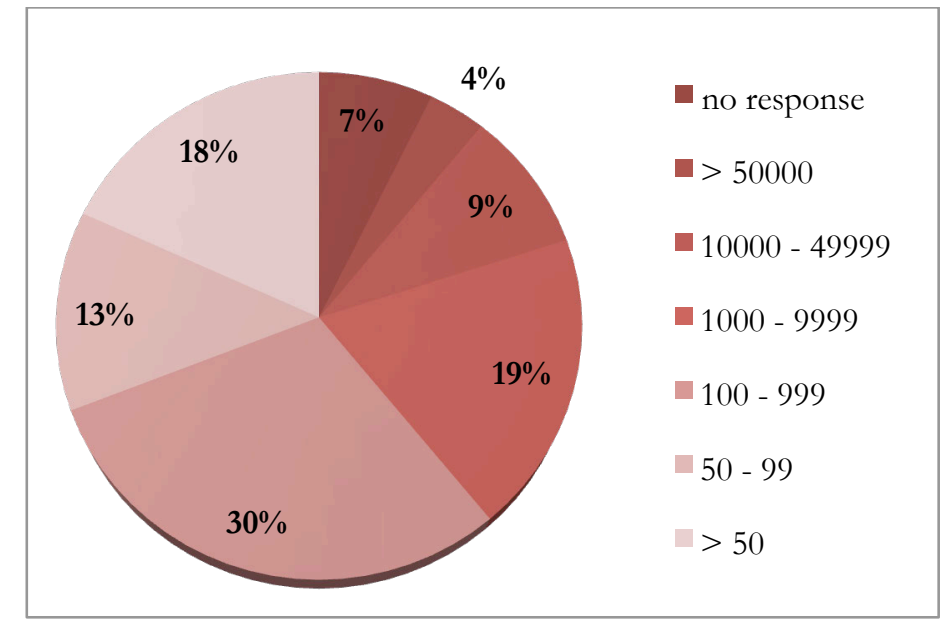

Figure 1a: Size acceding to the number of employees

12 Robert M. Groves, Don A. Dillman, John L. Eltinge, and Roderick J. A. Little, eds., Survey Nonresponse (John Wiley \& Sons, 2001). 


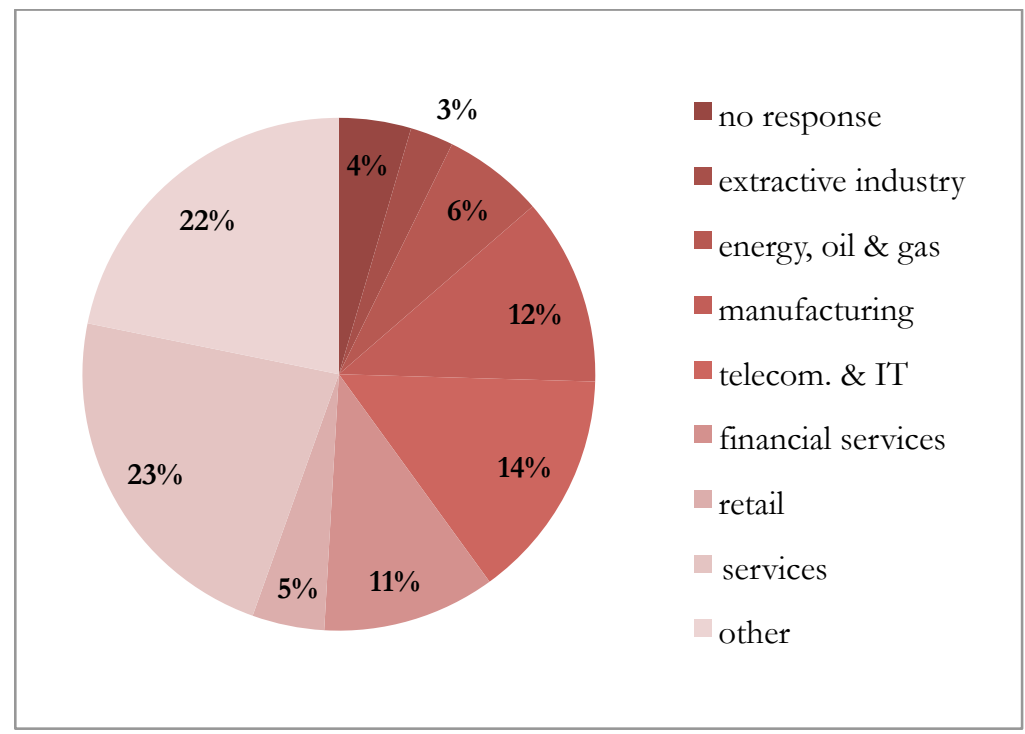

Figure 1b: Size according to industry

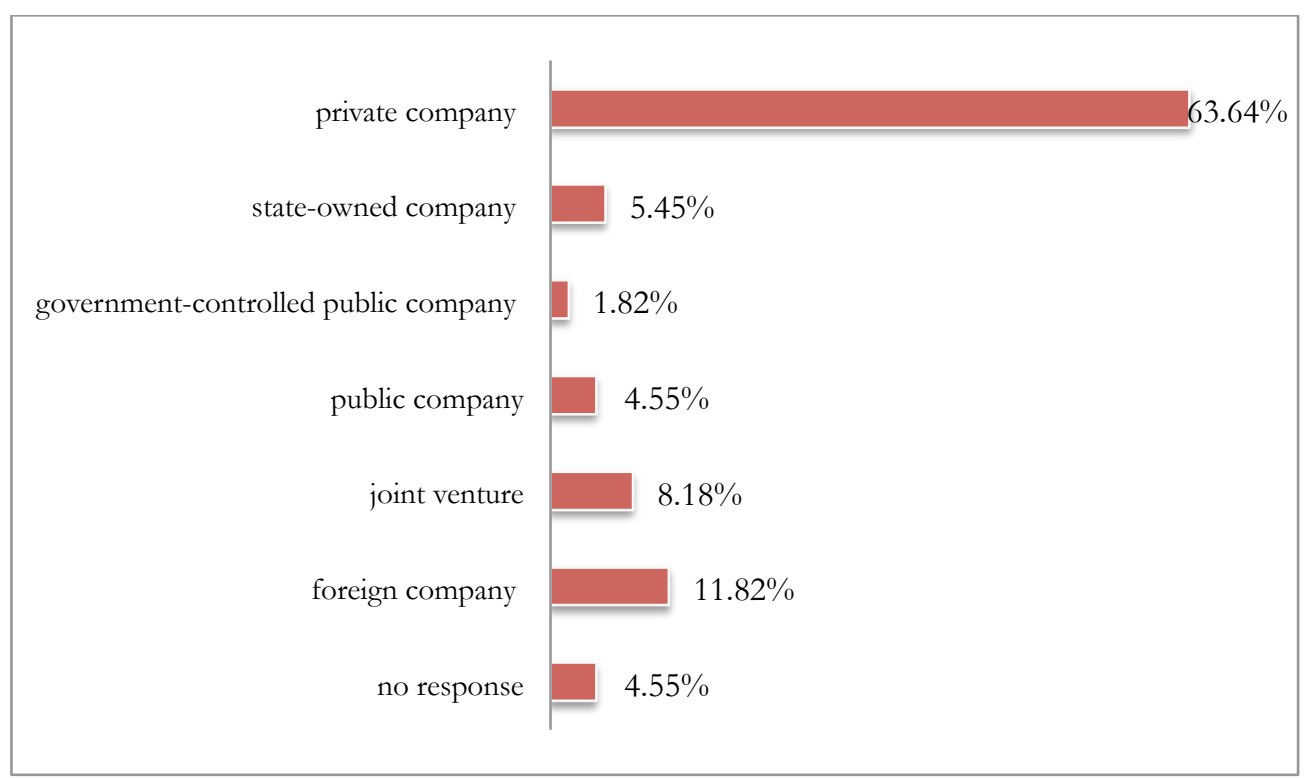

Figure 1c: Ownership Structure

\section{Frequency of Informal Practices: An Indicator of a Systemic Problem or a Key for Prioritization?}

The most basic, but also the most interesting, result is the relative frequency of informal practices, summarized below in Table 1. 
Funding of publications in regional press and broadcasts on regional TV and radio

Disregarding "conflict of interest" of regional managers, e.g. their use of companies affiliated with them, recruitment of relatives, etc.

Selecting vendors/contractors with whom regional managers have informal relationships or arrangements

Extortion of bribes by regional regulatory agencies: tax inspectorate, sanitation service, police, etc.

Receipt of kickbacks or other informal rewards (e.g. expensive gifts) by regional managers from vendors, suppliers and buyers

Paying for the services of regional regulatory agencies: tax inspectorate, customs, sanitation service, police, fire inspectorate, standardization agencies, etc.

Using company staff to carry out personal assignments for regional managers (assistance to family members, construction and decoration of housing, organization of holidays and entertainment)

Using informal connections and networks to obtain state orders (state procurement) and loans from state banks

Use of the "telephone rule"-informal pressure on regional managers and verbal instructions-by representatives of federal and regional authorities

Regional authorities' pressure on the company's regional managers to provide funding for their regional programs and projects

Selecting winners of open tenders at the regional level on the basis of informal relationships and arrangements

Paying salaries and bonuses to staff of regional subdivisions in cash without paying social tax

Use of company funds by heads of regional subdivisions to buy expensive cars, telephones, to pay for travel, etc.

Paying for or providing services (foreign trips, medical expenses, etc.) to regional executive authorities

Creating informal alliances with other companies in the region to exert influence on regional authorities

Receiving subsidies and tax benefits from regional authorities

Paying exorbitant board of directors' fees to cronies

\begin{tabular}{|c|c|c|}
\hline 19 & 61 & 27 \\
\hline 13 & 67 & 26 \\
\hline 13 & 66 & 28 \\
\hline 25 & 51 & 28 \\
\hline 5 & 65 & 36 \\
\hline 29 & 39 & 36 \\
\hline 6 & 61 & 41 \\
\hline 11 & 49 & 44 \\
\hline 7 & 50 & 48 \\
\hline 13 & 39 & 53 \\
\hline 10 & 42 & 55 \\
\hline 22 & 29 & 59 \\
\hline 5 & 45 & 60 \\
\hline 9 & 34 & 64 \\
\hline 2 & 33 & 70 \\
\hline 8 & 26 & 71 \\
\hline 3 & 30 & 75 \\
\hline
\end{tabular}




\begin{tabular}{|c|c|c|c|}
\hline $\begin{array}{l}\text { Paying for or providing services (foreign trips, medical } \\
\text { expenses, etc.) to regional legislative authorities }\end{array}$ & 6 & 26 & 74 \\
\hline Extortion of bribes by regional authorities & 10 & 23 & 73 \\
\hline $\begin{array}{l}\text { Using informal tools (compromising documents and } \\
\text { information, material from security services and } \\
\text { krugovaya poruka }{ }^{13} \text { ) against competitors }\end{array}$ & 7 & 25 & 73 \\
\hline $\begin{array}{l}\text { Paying police and the prosecution service to open or } \\
\text { close criminal cases }\end{array}$ & 8 & 22 & 75 \\
\hline $\begin{array}{l}\text { Using informal tools (compromising documents and } \\
\text { information, material from security services and } \\
\text { krugovaya poruka) to manage company staff }\end{array}$ & 3 & 28 & 74 \\
\hline Paying for favorable court rulings by the regional courts & 10 & 19 & 75 \\
\hline $\begin{array}{l}\text { Paying for tax audits and other inspections in regional } \\
\text { subdivisions with pre-agreed results }\end{array}$ & 4 & 20 & 82 \\
\hline $\begin{array}{l}\text { Using informal tools (compromising documents and } \\
\text { information, material from security services and } \\
\text { krugovaya poruka) to exert pressure on regional authorities }\end{array}$ & 6 & 9 & 87 \\
\hline $\begin{array}{l}\text { Lease of the company's production, office premises or } \\
\text { production equipment by regional managers for personal } \\
\text { gain }\end{array}$ & 1 & 12 & 96 \\
\hline $\begin{array}{l}\text { Receipt of commissions or other material benefits from } \\
\text { job candidates by heads of regional subdivisions }\end{array}$ & 3 & 3 & 99 \\
\hline
\end{tabular}

Needless to say, the priorities that can be determined on the basis of systemically used practices in a cross-company survey and an inner-company survey may differ significantly. We conducted two inner-company test surveys, one in the energy sector and one in the financial one.

The variation in the use of informal practices between companies can be substantial. For example, see the comparison of the prevalence of paying salaries and bonuses in envelopes (that is, in cash) between the cross-company and innercompany surveys in the energy sector data (Figure 2).

13 Joint responsibility or mutual concealment; Seilschaften in German. 

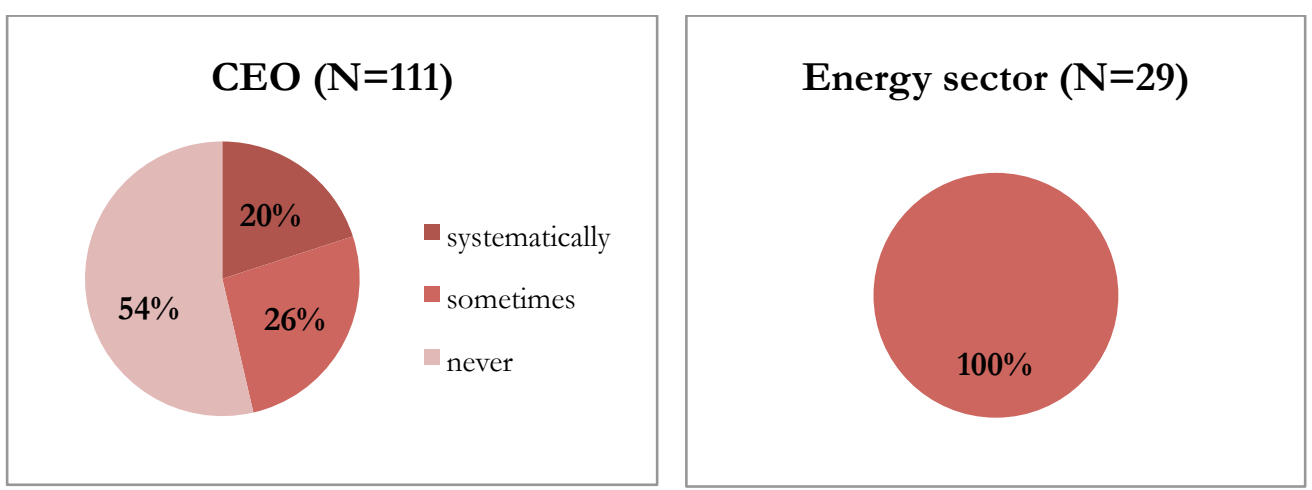

Figure 2: Prevalence of the practice of paying salaries and bonuses to staff in cash

Whereas this energy company seems to be ahead in its compliance with the social tax, it appears to lag behind when it comes to selecting the winners of open tenders on the basis of informal relationships and agreements (see Figure 3).
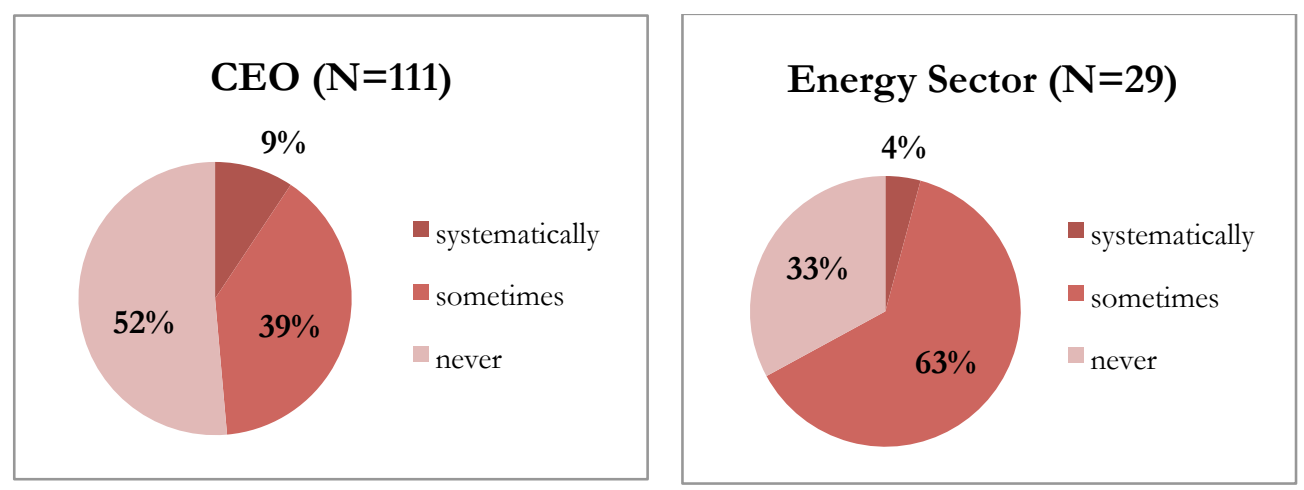

Figure 3: Prevalence of the practice of selecting winners of open tenders on the basis of informal relationships and agreements

Predictably, as a large company in the energy sector, it suffers more pressure from regional governments to finance their pet projects and programs (see Figure 4).


Figure 4: Pressure from regional governments to finance their pet projects and programs 
Such detailed inner-company data on the complete spectrum of informal practices would be of interest to the company's managers.

Overall, the findings suggest that the level of penetration of informal practices is sufficiently high to claim that such practices are fairly ubiquitous in the daily operations of Russian businesses. It is important, however, to assess the systemic nature of these practices. We experimented with a number of weighting schemes for systemically used practices, and determined just how different the top ten practices would be if we focused on these systemically used practices. We evaluated the relative importance of each practice by weighting respondents' answers using the following scale: 0 points for "never," 2 points for "sometimes," and 5 points for "systematically." Weighting is essential to identify the most systematically occurring problems for the purposes of inner-company management. The most systematically used practice scored 278 points (the average score was 156), while the least used practice acquired as little as 24 points (see Table 2). Practices scoring the highest number of points are excellent pointers for the required change, whereas the lowest scoring practices are a good proxy for a change that has already has taken place. ${ }^{14}$

\footnotetext{
${ }^{14}$ We include the least systematically used informal practices in order to illustrate changes that have happened since the transitional period in Russia in the 1990s. Practices listed at the bottom of the table scored high in the content analysis of the media and are still occasionally used, but they have lost their systemic nature and now serve as the best indicators of the effectiveness of the reforms conducted in their respective areas.
} 
Extortion of bribes by regional regulatory agencies: tax inspectorate, sanitation service, police, etc.

\begin{tabular}{l|c}
\hline $6.60 \%$ & 278 \\
\hline $6.60 \%$ & 278 \\
\hline $6.32 \%$ & 266 \\
\hline $6.24 \%$ & 263 \\
\hline $6.22 \%$ & 262 \\
\hline $5.22 \%$ & 220 \\
\hline $5.06 \%$ & 213 \\
\hline
\end{tabular}

Funding of publications in regional press and broadcasts on regional TV and radio

Disregarding "conflict of interest" of regional managers, e.g. their use of companies affiliated with them, recruitment of relatives, etc.

Selecting vendors/contractors with whom regional managers have informal relationships or arrangements

Paying for the services of regional regulatory agencies: tax inspectorate, customs, sanitation service, police, fire inspectorate, standardization agencies, etc.

Receipt of kickbacks or other informal rewards (e.g. expensive gifts) by regional managers from vendors, suppliers and buyers

Using company staff to carry out personal assignments for regional managers (assistance to family members, construction and decoration of housing, organization of holidays and entertainment)

Using informal connections and networks to obtain state orders (state procurement) and loans from state banks

Paying salaries and bonuses to staff of regional subdivisions in cash without paying social tax

Using informal tools (compromising documents and information, material from security services and krugovaya poruka) to manage company staff

Paying for tax audits and other inspections in regional subdivisions with pre-agreed results

Using informal tools (compromising documents and information, material from security services and krugovaya poruka) to exert pressure on regional authorities

Lease of the company's production or office premises or production equipment by regional managers for personal gain

Receipt of commissions or other material benefits from job candidates by heads of regional subdivisions Total

$5.06 \%$

\begin{tabular}{|c|c}
\hline $4.80 \%$ & 202 \\
\hline $4.68 \%$ & 197 \\
\hline $2.35 \%$ & 99 \\
\hline $1.90 \%$ & 80 \\
\hline $1.35 \%$ & 57 \\
\hline $0.97 \%$ & 41 \\
\hline $0.57 \%$ & 24 \\
\hline $100 \%$ & 4212 \\
\hline
\end{tabular}

Table 2: The most and the least systematically used informal practices (in the descending order by weighted points) 


\section{Corruption Mitigation: Business Executives' Perspective}

To complement the quantitative survey, we conducted 20 in-depth interviews with the CEOs participating in the study and four executive workshops with senior managers from three companies in the survey. These conversations helped us to identify four typical positions that executives take up in relation to corruption.

The first-toleration-is the most widespread among interviewees: "Because the whole society is corrupt, and unless systemic changes occur, corruption cannot be effectively dealt with and is widely accepted. It is not up to us to promote anticorruption changes; the government should take care of it."

The second approach—exploitation—is expressed openly only by a small minority: "Since Russian society is deeply corrupt, corruption should not only be accepted but also proactively used to advance business interests." In other words, the endemic nature of corruption makes it a legitimate instrument for doing business.

The third-avoidance_-is also articulated by a small minority: "Even in an endemically corrupt environment, where corruption is generally accepted, it is possible to avoid it and to run a business without it playing a role. Others may suffer from corruption but we can find a way to stay away from it."

The fourth-management of corruption—is shared by a select few: "Corruption is a problem and we are working on it, even where we are unable to change the environment."

These executives recognize corruption as a major risk and develop specific strategies and mechanisms to mitigate it. The four positions articulated above can be organized into a matrix demonstrating that the majority of executives are not prepared for a full-scale fight against corruption (the percentages were estimated by the interviewers). A range of psychological and technical factors prevent them from taking up the anti-corruption challenge. 
Attitudes to corruption

\section{Acceptance of corruption as a real risk to business}

Non-acceptance of corruption as a real risk to business

\section{\begin{tabular}{l|l} 
Passive attitude & Active attitude
\end{tabular}}

Toleration (60\%)

Management (15\%)

Avoidance (15\%)

Exploitation (10\%)

Table 3: Executives' attitudes to corruption

Failure to recognize corruption as a threat to their business (often at a subconscious level) or rationalization of a personal inability to deal with it effectively relieves executives of the additional responsibility of managing corruption at their level. ${ }^{15}$ Limited usefulness of top-down, government-driven approaches to corruption management, as well as a lack of knowledge of alternative company-specific methods, reduces executives' capacity to manage corruption effectively. Corporations tend to blame corruption in the public sector and hide internal corruption from the public, while the most important aspect of corruption-the interaction between the state and the firm—remains unscrutinised. ${ }^{16}$

To overcome this situation, corporate executives have to adopt what we call "reflective leadership." Reflective leaders see corporate responsibility as inclusive of the courage to confront external corruption proactively and of the will to enforce anti-corruption instruments to deal with the firm's internal corruption. As we have shown in this section, this is a particularly challenging task in emerging markets which are often ridden with endemic corruption.

\section{Managing Corruption: Reflective Leadership, Top- Down and Bottom-Up Approaches}

There are two distinct theoretical approaches to corruption management at company level. The first, the so-called top-down, prescriptive approach, is

\footnotetext{
${ }^{15}$ Vikas Anand, Blake E. Ashforth and Mahendra Joshi, "Business as Usual: The Acceptance and Perpetuation of Corruption in Organizations," Academy of Management Executive 19.4 (2005): 9-23; Peter Fleming and Stelios C. Zyglidopoulos, Charting Corporate Corruption: Agency, Structure and Escalation (Edward Elgar, 2009).

16 The question of how to mitigate corruption when dealing with public officials is discussed in Shekshnia, Ledeneva and Denisova-Schmidt, "Reflective Leadership vs. Endemic Corruption."
} 
advocated by international organizations such as the UN and the OECD and is supported by most national government signatories to their Anti-Corruption and Anti-Bribery Conventions. ${ }^{17}$ NGOs (non-governmental organizations) such as Transparency International also call upon firms to fight bribery both at the macro and at the individual company level and to promote business principles for countering bribery and codes of corporate conduct. These international organizations supply management policies and toolkits, information sessions, internal audits and guidelines, irrespective of the specific characteristics of the firm or the context in which it operates. ${ }^{18}$ For example, based on the findings of a survey conducted at 100 enterprises in 16 emerging markets, Transparency International recommends ${ }^{19}$ that companies become more publicly accountable: to be more transparent to their stakeholders; to make their anti-corruption programs publicly available; to publish exhaustive lists of their subsidiaries, affiliates, and joint ventures; and to disclose other information related to their operations.

The second approach, the bottom-up approach, is company-centered and grounded in management and social theories that focus on corruption mitigation within a complex social context, inclusive of such contingencies as the individual, the organization, or its business environment, as well as social and cultural contexts. ${ }^{20}$ Having reviewed the management literature on government corruption, Galang argues that a firm's behavior in a corrupt environment is determined by two factors: the firm's political resources and the dependence of the industry in which the firm operates on government regulations. Factors such as a country's institutional development, and the corporate culture and structure of the firm also

\footnotetext{
17 See the leading national legislations such as the U.S. Foreign Corrupt Practices Act (the FCPA) (1977), the U.K. Anti-Corruption Act (2010), and the UN and OECD conventions: United Nations Convention against Corruption, www.unodc.org/unodc/en/treaties/CAC/, and OECD Anti-Bribery Convention, http://www.oecd.org/department/0,3355,en_2649_34859_1_1_1_1_1,00.html.

18 See Transparency International, "Business Principles for Countering Bribery," December 17, 2013, http://www.transparency.org/whatwedo/tools/business_principles_for_countering_bribery.

19 Transparency International, "Transparency in Corporate Reporting: Assessing Emerging Market Multinationals," October 16, 2013, http://www.transparency.org/whatwedo/pub/transparency_in_corporate_reporting_assessing_emerging_mark et_multinational.

${ }^{20}$ Fleming and Zyglidopoulos, Charting Corporate Corruption and Galang, "Victim or Victimizer."
} 
play a part. ${ }^{21}$ Galang identifies four distinct strategic approaches to government corruption:

The Altering strategy (high regulatory dependence/high level of political resources), which leads to engagement with the government, institutional change and regulatory capture; this strategy benefits both the firm and the economy.

The Avoidance strategy (low regulatory dependence/high level of political resources), which leads to self-restraint, non-investment, and formation of business groups; this strategy benefits the firm.

The Alliance strategy (high regulatory dependence/low level of political resources), which leads to networking and forming joint ventures; this strategy benefits both the firm and the economy.

The Accedence strategy (low regulatory dependence/low level of political resources), which leads to acceptance of the rules of the game proposed by government officials and bribing; this strategy benefits both the firm and the economy.

In his theoretical attempt to organize existing internal corruption mitigation mechanisms, Lange identifies four types (functions) of corruption controls by organizations: 1) autonomy reduction (AR); 2) consequence systems (CS), ensuring reward and punishment); 3) environmental sanctioning, "in which an organization interprets and transmits to the member external pressures for legal/regulatory compliance and social conformity" (ES); and 4) "intrinsically oriented controls, in which the organization fosters and facilitates the member's own inclinations to reject corrupt behavior" (IC). ${ }^{22}$ Other scholars suggest that rationalization at individual and organizational levels are important obstacles to effective prevention of corruption. They call for the instigation of organizational mechanisms and values which prompt corruption to be recognized as a "form of unaccepted deviance,"23 which could be achieved through training and discussions ${ }^{24}$ or by better controls

\footnotetext{
21 Ibid.

22 Donald Lange, "A Multidimensional Conceptualization of Organizational Corruption Control," Academy of Management Review 33.3 (2008): 710-729.

23 Fleming and Zyglidopoulos, Charting Corporate Corruption, 134.

${ }^{24}$ Anand, Ashforth and Joshi, "Business as Usual."
} 
and surveillance, including ethical screening at entry, and job security measures that would reduce pressures on employees. ${ }^{25}$ Based on interviews with Swiss and Austrian white-collar criminals convicted for fraud, corruption, bribery, embezzlement or misappropriation of funds, Schuchter also recommends developing and maintaining effective internal and external control. ${ }^{26}$ Sentenced persons (senior executives, CEOs and owners of large enterprises) saw some gaps in the internal control system and judged it as an "invitation to act." Moreover, long-term trust relationships between external auditors and convicted managers made revisions and other inspections less contentious.

While top-down, prescriptive approaches to corruption management have failed to produce significant results despite two decades of high-profile international and national anti-corruption campaigns, most theoretical models have not been empirically tested. We see the way forward in developing contingency-based models and integrating data on specific practices and strategies to mitigate them. A combination of top-down and bottom-up approaches, using existing theoretical frameworks on corruption mitigation and effective leadership, with hands-on analysis and training, will bring corporate leaders to the forefront in the fight against corruption.

\section{Corruption Management: Strategic Approaches}

Our study has provided some insights into how executives who subscribe to corruption management employ mitigation strategies and choose instruments to achieve their goals effectively. The study identifies at least two distinct approaches to agenda-setting. The first can be seen as universal, and is associated with the top-down introduction of best practices world-wide. Codes of practice and ethical guidelines are most common in this respect and are implemented irrespective of companies' specific corruption risks. The actions of executives are often driven by changes in national legislation, policies advocated by international organizations and national governments, corporate benchmarking, pressure from headquarters,

${ }^{25}$ W. Steve Albrecht, Conan C. Albrecht and Chad O. Albrecht, "Fraud and Corporate Executives: Agency, Stewardship and Broken Trust," Journal of Forensic Accounting 5.1 (2004): 109-130.

26 Alexander Schuchter, Perspektiven verurteilter Wirtschaftsstraftäte: Gründe ihrer Handlungen und Prävention in Unternehmen (Gabler, 2012). 
etc. One participant at an executive workshop explained: "We went to a training session organized by our British shareholder and heard about some interesting anti-corruption instruments. We became quite excited and implemented them back home, only to realize that that they neither fitted our context, nor produced any impact."

The second uses a bottom-up approach for tackling the specific corruption risks associated with informal practices when these are widespread in the company, that is, with a concrete set of objectives in mind. One of the interviewed CEOs framed it as follows: "We spend hundreds of millions on IT and I know that we suffer from kickbacks received by our purchasing managers from vendors. I want to fight this so I have set three goals: reduction of our IT-related costs by 10 percent next year; a review of the list of our IT vendors in order to get rid of companies affiliated with our managers in some way, and uncovering a few cases of kickbacks and making them public." A combination of both top-down and bottom-up approaches would constitute best practice. However, we found that in the majority of cases executives either do not try or, if they do try, struggle, to identify a short-list of damaging practices. We propose a simple yet comprehensive five-step approach to identifying targets of anticorruption strategies.

First, the development of a comprehensive list of practices using in-depth interviews with executives and the content analysis of business publications in the national and regional media. It is essential to keep the original formulation of practices while verifying the list against existing classifications. ${ }^{27}$

Second, experts with deep company knowledge (senior executives and business unit managers) should be invited to add to the list of practices, especially where these are specific for their own company. It would be practical to keep the list manageable so that it can be converted into a simple-to-answer questionnaire. Any omission may lead to failure to identify some of the most widespread practices and those that are taken for granted.

\footnotetext{
27 See, e.g., Transparency International, "Corruption in the U.K.: Overview and Policy Recommendations, Parts 1-3," June 2011, http://www.transparency.org.uk/our-work/publications/81-corruption-in-the-uk--overview-\&policy-recommendations, and Transparency International, “Corruption: A Beginner's Guide," December 2012, http://www.transparency.org.uk/our-work/publications/10-publications/454-corruption-a-beginners-guidewhat-is-corruption.
} 
Third, once the final list is determined, company employees would be asked to assess whether, in their experience, these practices occur systematically, occasionally, or never. Anonymity of respondents must be assured. A large random sample of firms' employees at all levels of the hierarchy is recommended. From the respondents' point of view, it would be best if the questionnaire was administered on-line or by an outside consultant who does not report directly to the management. The survey would then produce a list of the informal practices most frequently recognized and acknowledged by company employees. This would then form a foundation for the development of specific anti-corruption strategies.

Fourth, the CEO and senior corporate leaders should select a limited number of specific practices they want to target, identify specific goals they aim to achieve with regard to each of them, and select monitoring instruments. The choice of appropriate execution strategies will be discussed in the next section. The proposed instrument allows executives to deal with specific corruption risks rather than corruption in general, to direct limited resources to important targets, to communicate the anti-corruption strategy effectively, and to monitor the change.

The suggested methodology is not without limitations. It is subject to bias, especially when the design of the questionnaire is dominated exclusively by senior executives of the organization who have extensive but one-sided knowledge of their organization. The number of questions in the survey should remain manageable, which implies limited contextualization. Respondents are asked to assess frequency of their experience of informal practices, but where they are not directly involved with the practice, they will inevitably report their perceptions. Although there is normally a perception bias in corruption studies-personal experience of involvement with corruption is reported by far fewer respondents than the omnipresent nature of corruption in general-it is likely to be compensated for by the tendency of respondents to save "corporate face" and to report on a need-toknow basis in the context of the in-house study of the firm. Our coaching and teaching experience shows, however, that the recognition effect of informal practices (when things are named in a familiar way), contextualized design of the questionnaire, large size and diversity of the sample, as well as the genuine willingness of senior executives to target corruption at company level, ensures the success of the exercise.

EDMOND J. SAFRA RESEARCH LAB, HARVARD UNIVERSITY • HOW TO MITIGATE CORRUPTION IN EMERGING 21 MARKETS: THE CASE OF RUSSIA • SHEKSHNIA, LEDENEVA, DENISOVA-SCHMIDT • FEBRUARY 6, 2014 


\section{Corruption Management Strategies at the Company Level}

Our research into the specific approaches to corruption mitigation adopted by companies operating in Russia confirmed the relevance of Lange's model of organizational controls. Executives who subscribe to the management of corruption adopt two distinct types of strategies when dealing with it-control and prevention-and use two distinct transmitting channels for their actionsorganizational hierarchies and personal networks.

In the control mode, managers deal with informal practices reactively after these practices have already taken place and damaged the business. For example, the CEO of an oil company publicly fired a successful regional manager for selling gasoline to an informally affiliated company at a lower price. In the prevention mode, executives deal with risks which might hurt the business if they occur in the future and proactively look out for practices that may be indicative of those risks. For example, the CEO of a mining company issued an executive order prohibiting sales managers from sponsoring foreign trips for government officials.

Hierarchical or formal strategies imply the use of such institutional instruments as executive orders and procedures, codes of conducts, incentive systems, etc.

Network-based or informal tools are unwritten, and are spread through unofficial channels such as personal networks, informal agendas, informal signals, and informal incentives. ${ }^{28}$

Our interviewees point out that in addition to formal policies, it is crucial to communicate the leadership's degree of commitment informally. Informal incentives and signals can be very effective in mitigating corruption risks and preventing specific informal practices. One CEO gave us an example of an informal back-up of formally announced policies. He set an example for his regional directors and declared a personal commitment to fight conflicts of interest among managers working with informally affiliated vendors and suppliers. He sent a strong signal through his company-wide informal network that he would not tolerate any divergence from the new party line, no matter how close his relationships with a

${ }^{28}$ Ledeneva, Can Russia Modernise. 
particular manager had been in the past. According to him, that informal warning had a stronger educational impact than all formal policies and procedures developed to tackle the issue. The combination of two modes and two types of transmitting channels discussed above creates four ideal types of corruption management at company level, as presented in Table 4.

\begin{tabular}{l|l|l}
$\begin{array}{l}\text { Types of Corruption } \\
\text { Management }\end{array}$ & Control & Prevention \\
\hline $\begin{array}{l}\text { Formal channels } \\
\text { (hierarchical, official, } \\
\text { written, codified) }\end{array}$ & $\begin{array}{l}\text { Reactive management } \\
\text { through formal channels (1) }\end{array}$ & $\begin{array}{l}\text { Proactive management } \\
\text { through formal channels } \\
(3)\end{array}$ \\
\hline $\begin{array}{l}\text { Informal channels } \\
\text { (network-based, unofficial, } \\
\text { unwritten, non-codified) }\end{array}$ & $\begin{array}{l}\text { Reactive management } \\
\text { through informal channels (2) }\end{array}$ & $\begin{array}{l}\text { Proactive management } \\
\text { through informal } \\
\text { channels (4) }\end{array}$ \\
\hline
\end{tabular}

Table 4: Types of corruption management at the firm level

The four types are ideal types. Thus, in the example above, the CEO has applied proactive management through informal channels, yet he has also targeted widespread practices of conflict of interest, indicating that his actions may have been reactive. Below, we illustrate the ideal types with examples.

1. Reactive/formal. An internal audit investigation of acquisition of assets in a new region results in identifying a conflict of interest on the part of the responsible manager. The CEO fires the manager for abuse of corporate office.

2. Reactive/informal. With the help of the founder-CEO's network, a bank employee caught stealing $\$ 200,000$ from a bank client is not only sacked, but a criminal case against him is opened and a five-year sentence handed down. Reactive in one case, the sentence is a powerful deterrent for other employees.

3. Proactive/formal. Rotating membership in a tender committee every two years as a matter of policy prevents long-term informal affiliations of its members, bias in decisions, and inflated contracts for affiliated vendors and suppliers of large oil and gas companies.

4. Proactive/informal. Before introducing a new policy with regard to purchasing managers' expenses, a Russian energy company CEO attends a 
number of meetings with them and discusses the proposed policy off the record. These meetings allow the managers to share concerns, raise important questions, and create awareness, and gives them a chance to adjust their routines in advance of publication of the formal policy.

None of the described types of strategies is superior in delivering effective management of corruption. The choice is dependent on such contingencies as the nature and prioritization of specific corruption risks, the initiators, beneficiaries and cost bearers, the resources available to the CEO, and the corporate culture of the firm. CEOs of companies operating in an endemically corrupt environment need to master all four types and to develop the largest possible arsenal of anticorruption strategies.

\section{Conclusion}

In conclusion, let us return to what we consider an effective approach to managing corruption in endemically corrupt environments such as in Russia. Action points for CEOs and other senior business leaders may be summed up as follows:

Make corruption management one of the CEO's top priorities. Start by recognizing corruption as a major risk for the company and its stakeholders, and overcome blind spots and lack of recognition with regard to corruption risks. Channel the priority status of the anti-corruption management through both the organizational hierarchy and informal networks.

Use a bottom-up, ethnographic approach to identify specific practices that are particularly problematic. Spend time and other resources investigating which specific informal practices inflict the most systematic damage on the corporation.

Slice the corruption "elephant" into smaller pieces that can be more easily tackled in endemically corrupt environments. Once identified, target these specific practices, not corruption in general.

Combine formal tools and informal influence. Effective anti-corruption strategies are based both on formal tools (such as hotlines, codes of conduct, open tender competition and standard policies and procedures) and informal influence (role modeling, peer pressure and other instruments of informal governance). 
Provide training to give people the skills to identify, articulate, measure and manage corrupt practices. Most CEOs mitigating the risks of business corruption in Russian companies agree that making key employees at every level of the organization active participants in the anti-corruption strategy is critical for its success. Conducting detailed surveys on informal practices and providing a platform for discussion of the corruption elephant-in-the-room is an important addition to anti-corruption legal training and integrity education.

A leader's will to control the risks associated with corruption, to go beyond general programs of anti-corruption awareness, and to offer specific skills to identify, articulate, measure and manage corrupt practices can and does work in endemically corrupt environments. The successful and effective implementation of these approaches depends not only on the leader's engagement and attitudes towards this important issue, but also on the framework of the industry in which they work. 


\section{About the Authors}

Stanislav Shekshnia is a Professor of Entrepreneurship at INSEAD and a Program Director at INSEAD Global Leadership Center at Fontainebleau.

Alena V. Ledeneva is a Professor of Politics and Society at the University College London (UCL), UK.

Dr. Elena Denisova-Schmidt, MBA, is a lecturer at the University of St. Gallen (HSG) and an Edmond J. Safra Network Fellow at Harvard University.

\section{Acknowledgments}

We are grateful to Herminia Ibarra at INSEAD, Malcolm Salter at Harvard Business School, and Carl Fey, Valery Yakubovich and other participants in the Russian research caucus for their questions, criticisms and suggestions (CAU915), August 6, 2012, The Academy of Management "The Informal Economy" Annual Meeting Programme, Boston. 


\section{HARVARD UNIVERSITY}

\section{Edmond J. Safra Foundation Center for Ethics}

\section{Working Paper Series}

Institutional Corruptions

by Lawrence Lessig

WORKING PAPER

Edmond J. Safra Research Lab Working Papers, No. 1

Strengthening the Theory of Institutional Corruptions:

Broadening, Clarifying, and Measuring

by Donald W. Light

Edmond J. Safra Research Lab Working Papers, No. 2

Influence Incognito

by Brooke Williams

Edmond J. Safra Research Lab Working Papers, No. 3

Professionalism and Moral Behavior:

Does A Professional Self-Conception Make One More Unetbical?

by Maryam Kouchaki

Edmond J. Safra Research Lab Working Papers, No. 4

Short-Termism At Its Worst: How Short-Termism Invites Corruption...

and What to Do About It

by Malcolm S. Salter

Edmond J. Safra Research Lab Working Papers, No. 5

What Institutional Corruption Shares with Obscenity

by Gregg Fields

Edmond J. Safra Research Lab Working Papers, No. 6

Investment Consultants and Institutional Corruption

by Jay Youngdahl

Edmond J. Safra Research Lab Working Papers, No. 7

Does the Gender of Directors Matter?

by Miriam Schwartz-Ziv

Edmond J. Safra Research Lab Working Papers, No. 8

Finding Solutions to Institutional Corruption:

Lessons from Cognitive Dissonance Theory

by Lisa Cosgrove and Robert Whitaker

Edmond J. Safra Research Lab Working Papers, No. 9 
Democracy in Poverty: A View From Below

by Daniel M. Weeks

Edmond J. Safra Research Lab Working Papers, No. 10

What's the Big Deal?: The Ethics of Public-Private Partnerships Related to

Food and Health

by Jonathan H. Marks

Edmond J. Safra Research Lab Working Papers, No. 11

Tax-Exempt Corruption: Exploring Elements of Institutional Corruption in

Bond Finance

by Zachary Fox

Edmond J. Safra Research Lab Working Papers, No. 12

Second Thoughts on Second Opinions: Conflicted Advisors Reduce the Quality

of Their Advice When They Know They Will be "Second-Guessed"

by Sunita Sah and George Loewenstein

Edmond J. Safra Research Lab Working Papers, No. 13

Culture Wars: Rate Manipulation, Institutional Corruption, and

the Lost Underpinnings of Market Conduct Regulation

by Justin O'Brien

Edmond J. Safra Research Lab Working Papers, No. 14

Institutional Corruption and the Crisis of Liberal Democracy

by William English

Edmond J. Safra Research Lab Working Papers, No. 15

Two Concepts of Corruption

by Dennis F. Thompson

Edmond J. Safra Research Lab Working Papers, No. 16

Think Tanks' Dirty Little Secret: Power, Public Policy, and Plagiarism

by J.H. Snider

Edmond J. Safra Research Lab Working Papers, No. 17

Rooting Out Institutional Corruption To Manage Inappropriate Off-Label

Drug Use

by Marc A. Rodwin

Edmond J. Safra Research Lab Working Papers, No. 18

Divided Loyalties: Using Fiduciary Law to Show Institutional Corruption

by Michael Pierce

Edmond J. Safra Research Lab Working Papers, No. 19

Political Finance in the United Kingdom

by Timothy Winters

Edmond J. Safra Research Lab Working Papers, No. 20 
Blinding as a Solution to Institutional Corruption

by Christopher Robertson

Edmond J. Safra Research Lab Working Papers, No. 21

A Passport at Any Price? Citizenship by Investment through the Prism of

Institutional Corruption

by Laura Johnston

Edmond J. Safra Research Lab Working Papers, No. 22

Independent Drug Testing to Ensure Drug Safety and Efficacy

by Marc A. Rodwin

Edmond J. Safra Research Lab Working Papers, No. 23

Brazil's Case Against Private-Sponsored Events for Judges:

A Not-yet-perfect Attempt at Fighting Institutional Corruption

by José Vicente Santos de Mendonça

Edmond J. Safra Research Lab Working Papers, No. 24

Institutional Corruption: A Fiduciary Theory

by M.E. Newhouse

Edmond J. Safra Research Lab Working Papers, No. 25

"You're Not Just a Paid Monkey Reading Slides:" How Key Opinion Leaders

Explain and Justify Their Work

by Sergio Sismondo

Edmond J. Safra Research Lab Working Papers, No. 26

The Power of Perception: Reconciling Competing Hypotheses about the Influence

of NRA Money in Politics

by Arjun Ponnambalam

Edmond J. Safra Research Lab Working Papers, No. 27

Does Trust Matter? Corruption and Environmental Regulatory Policy in

the United States

by Oguzhan Dincer and Per Fredriksson

Edmond J. Safra Research Lab Working Papers, No. 28

Singapore Sling: How Coercion May Cure the Hangover in Financial

Benchmark Governance

by Justin O'Brien

Edmond J. Safra Research Lab Working Papers, No. 29

Justification of Academic Corruption at Russian Universities:

A Student Perspective

by Elena Denisova-Schmidt

Edmond J. Safra Research Lab Working Papers, No. 30 
Fighting Corruption in Education: A Call for Sector Integrity Standards by Mihaylo Milovanovitch

Edmond J. Safra Research Lab Working Papers, No. 31

Annals of Crony Capitalism: Revisiting the AIG Bailout

by Malcolm S. Salter

Edmond J. Safra Research Lab Working Papers, No. 32

From "Institutional" to "Structural" Corruption: Rethinking Accountability in a World of Public-Private Partnerships

by Irma E. Sandoval-Ballesteros

Edmond J. Safra Research Lab Working Papers, No. 33

The Open Government Index Initiative: A Colombian Tool for Preventing

Institutional Corruption

by Juan Pablo Remolina

Edmond J. Safra Research Lab Working Papers, No. 34

Judicial Independence in Latin America and the (Conflicting) Influence of Cultural Norms

by Roberto Laver

Edmond J. Safra Research Lab Working Papers, No. 35

How to Mitigate Corruption in Emerging Markets: The Case of Russia

by Stanislav Shekshnia, Alena V. Ledeneva and

Elena Denisova-Schmidt

Edmond J. Safra Research Lab Working Papers, No. 36 


\section{With Special Thanks to our Working Paper Series Board Members:}

\section{Advisory Board}

Marcia Angell

Arthur Applbaum

Marguerite Avery

Mahzarin Banaji

Max Bazerman

Archon Fung

David Korn

Nancy Rosenblum

Malcolm Salter

Dennis Thompson

\section{Editorial Board}

Lisa Cosgrove

Oguzhan Dincer

William English

Gregg Fields

Paul Jorgensen

Aaron Kesselheim

Genevieve Pham-Kanter

Marc Rodwin

Susannah Rose 